\title{
3rd ICTs and Society Meeting; Paper Session - Theorizing the Internet; Paper 3: How to defend the original, multi- criteria theories of Information Society?
}

\author{
Laszlo Z. Karvalics \\ University of Szeged, e-mail: zkl@hung.u-szeged.hu
}

\begin{abstract}
To summarize and illustrate Frank Webster's main theses and arguments on the Information Society domain, we used three pieces of his oeuvre, forming theses (T1-9) from his strong statements. Before a more detailed analysis we passionately argue against these theses. In our view the original concept of Information Society is complex and holistic, and was formulated on civilization theory level. The only methodologically acceptable approach is the multi-criteria definition. Since Webster constantly refuses to accept it, and insists on using an information density-based definition instead of it, all his main statements become false.
\end{abstract}

Keywords: Information Society, Frank Webster, multi-criteria theories, historicity

Frank Webster's Theories of the Information Society is a standard item in Information Society Studies curricula. Although he has a manifest critical position against the Information Society narrative, he is, after all, usually cited as one of the main thinkers of the field. $\mathrm{He}$ is also a respectful author of "Information Society" articles in leading handbooks. ${ }^{1}$

Avoiding the context with the previous debates, ${ }^{2}$ I see the following problems with the Websterian view of Information Society:

- His celebrated and often-cited "analytic approaches" are (more or less) supporting the information society theory but these are NOT equal with it.

- The basic element of his definition is a low level misinterpretation of the so-called information-centricity instead of using high level abstraction of social complexity

- It results in an inconsistently rearranged "Pantheon" of Information Society thinking with missing heroes and worthless numbers

\footnotetext{
1 'Information Society', in Smelser-Baltes (2002) 'The Information Society: Conceptions and Critique', ELIS (2003)

${ }^{2}$ For example: Gane (2005).
}

- Painful ahistoricity of his theses

- Relativization of the importance of paradigm shift, discounting the discourse itself.

The goal of the following "long summary" is to prepare my presentation in the 3rd International ICTs-and-Society Network meeting on July 1 in Barcelona (Anti-Webster, or how did Frank Webster successfully soften up the Information Society discourse), providing background material for the debate.

\section{Information Society - the Webste- rian view and interpretation}

To summarize and illustrate the main theses and arguments of Frank Webster on the Information Society domain, we use three pieces of his oeuvre. The "classics"' (Theories of the Information Society - ThIS) (Webster, 1995, 2006), its current recapitulation (The Information Society Revisited - ISR) (Webster, 2002) and a smaller, but talkatively reflective paper (Understanding the Information Domain: The Uneasy Relations between Sociology and Cultural Studies and the Peculiar Ab- 
sence of History - UID) ${ }^{3}$. We form(alize) theses (T1-9) from his strong statements for further analysis.

"Most definitions of the information society offer a quantitative measure (number of whitecollar workers, percentage of GDP devoted to information, etc.) and assume that, at some unspecified point, we enter an information society when this begins to predominate. But there are no clear grounds for designating as a new type of society one in which all we witness is greater quantities of information on circulation and storage." (ThIS, p. 22)

They (the information society theorists) "rush to interpret these in terms of different forms of economic production, new forms of social interactions, innovative processes of production or whatever.... They often fail to establish in what ways and why information is becoming more central today." (ThIS, p. 8-9)

T1. We have to abandon the multi-criteria definitions of Information Society because they have no information-centric foundation

T2. Since the information density is the only new phenomenon in the contemporary societies, there is a need for a well established theory on the role of information in them

That is the explicit role of his book: "to scrutinise major contributions towards our understanding of information in the modern world." (ThIS, p.3) "In this book I shall be considering various perspectives on "information" in the contemporary world." (ThIS, p.6) "The main purpose of this book has been to examine the significance of information in the world today" (ThIS, p. 263). "Conceiving contemporary societies ... commentators increasingly began to talk about "information" as a distinguishing feature of the modern world thirty years or so ago. The prioritisation of information has maintained its hold now for several decades...." (ThIS, p. 2)

\footnotetext{
${ }^{3}$ In: Rayward (2008)
}

T3. Theories of the Information Society is just accidentally about the "Information Society" narrative itself: it is about information-related approaches in contemporary social sciences. ${ }^{4}$

"What is an information society? ... It is possible to distinguish five definitions of an information society. (Th/S, p. 8-9) 1. technological 2. economic 3. occupational 4. spatial 5. cultural." (The $6^{\text {th }}$ definition is based on the growing importance of theoretical knowledge. ${ }^{5}$ )

T4. There is no unified, complex, holistic concept, only different, analytically separable approaches ${ }^{6}$, "various images of the information society." (ThIS, p.3)

Alvin Toffler's suggestion is that "the world has been decisively shaped by three waves of technological innovation." (ThIS, p. 9)

T4.1. (Technological) Alvin Toffler's "third wave" concept is a technological definition

"Once the greater part of economic activity is taken up by information activity rather than, say, subsistence agriculture or industrial manufacture, it follows that we may speak of an information society. ... much of the pioneering work was done by the late Fritz Machlup." (ThIS, p.13)

T4.2. (Economic) Identifying the information industries, Fritz Machlup is a pioneer information society thinker

\footnotetext{
${ }^{4}$ "The term (Information Society) perhaps has some heuristic value for the social scientist ..., in so far as it encourages scholars to focus attention on an indisputably important feature of the world today - information" (ISR, p. 22).

5 "The character of information is such as to have transformed how we live." (ThIS, p. 9) "The most persuasive conception of an information society, that which centres on the role of theoretical knowledge, is the least commonly suggested by information society adherents". (ThIS, p.31)

6 "This chapter has examined six analytically separable conceptions of the information society". (ISR, p. 22). The Wikipedia also prefers the term „analytically separable".
} 
Bell's „suggestion is that we have achieved an information society when the preponderance of occupations is found in information work. ...we inhabit an information society, since the 'predominant group [of occupations] consists of information workers."' (ThIS, p.14).

T4.3. (Occupational) Daniel Bell's definition of information society is occupational.

The spatial „conception of the information society, while it does draw on economics and sociology, has at its core the geographer's stress on space. Here the major emphasis is on information networks... (ThIS, p. 17) (but) "why should the presence of networks lead analysts to categorise societies as information societies?" (ThIS, p.18)

T4.4. (Spatial) The "spatial approach" is about networks and information flow - and the information society is defined by the presence of networks.

"What these definitions share is the conviction that quantitative changes in information are bringing into being a qualitatively new sort of social system, the information society." (ThIS, p.9) "The fact that there is now a great deal more information around than even a decade ago, and that this is demonstrable from everyday experiences (from watching television round the clock, through electronic banking services, to a significant increase in the information intensity of a good deal of modern-day work), has encouraged commentators to declare, more confidently than ever, that we inhabit an information society." (ISR, p. 22) "Those who conceive of an information society readily suppose that it is a higher stage of development toward which others are - or should be - moving. It assumes that information in increased volume and moving with greater velocity, combined with undeniably more knowledge, make for a better way of life, ignoring ways in which they can be used by, and developed for, maintaining and even consolidating established patterns." (UID, p. 10)

"The assumption here is that sheer expansion of information results in a new society." (ThIS, p. 23). If there is just more information, then it is hard to understand why anyone should suggest that we have before us something radically new (ThIS, p. 22). In this way each definitions reasons in much the same way: there is more information nowadays, therefore we have an information society." (ThIS, p. 9) "...there is evidence of there being more information in society today, therefore we have an information society." (ThIS, p. $23)^{7}$ (It is an) "unsupportable supposition of information society theorists that quantitative increases in information lead to qualitative social changes." (ISR, p. 22)

T5. More information does not result a radically new society, despite of the assumptions of "enthusiasts." There is no reason to call this "new" information society.

There are "doubts about the validity of the notion of an information society." (ThIS, p. 31) "I find the concept of information society unsatisfactory." (ISR, p. 22) "I find the conception of information society of limited use. In this I share the view of Manuel Castells when he declares that 'we should abandon the notion of 'information society'." (ISR, p. 22) "It has argued that all (the six analytically separable conceptions) are suspect to a greater or lesser degree, so much so that the idea of an information society cannot be sustained. In each case defining criteria are imprecise and vague." (ISR, p. 31) We can also see the "imprecise use of the term 'information'." (ISR, p. 22) There are "inconsistencies and lack of clarity as regards criteria used to distinguish an information society." (ISR, p. 22)

\section{T6. It is better not to use the term "infor- mation society"}

"Daniel Bell's conception of the information society was singular both in its intellectual sophistication and in its ambition to paint the big picture in sociological thinking during the 1970s." (UID, p. 20) "Manuel Castells's conception of the network society signalled a return to the scale and scope offered by Bell,

\footnotetext{
${ }^{7}$ After all, just because there are many more automobiles today than in 1970 does not qualify us to speak of "car society" (ThIS, p. 22).
} 
notably in being a macro analysis that combined theory and empirical evidence." (UID, p. 1)

T7. There are only two authors (Daniel Bell and Manuel Castells) on the level of "grand narrative" or "high theory"

"Most of the thinkers I examine in this book address informational trends directly" (ThIS, $\mathrm{p}$. 5), „none of the latter denies that information is of key importance to the modern world"... two of them give "less direct attention to the informational domain." (ThIS, p. 5)

T8. Jean Baudrillard, Zygmunt Bauman, Herbert Schiller, Anthony Giddens and Jürgen Habermas are important theorists of information society

"I advocate a historical approach to the study of information." (UID, p. 12) "Why has there not yet been a sustained historical analysis of the 'information revolution'." (UID, p. 26) We "dedicated much of our research time trying to produce a 'long history' of the 'information revolution'." (UID, p. 6) “... 'ahistorical historicism' this view that assumed direction of change from a point of origin (generally industrialism) without a serious analysis of how and why change has come about. What is presented is a chronicle of outcomes of change, but absent is any account of the causes, or even a close chronology, of change." (UID, p. 10)

T9. A profound historical foundation is needed instead of the ahistorical approaches

\section{Anti-Webster: Theses and antithe- ses}

T1. We have to abandon the multi-criteria definitions of Information Society because the lack of their information-centric foundation

FALSE: The original concept of Information Society is complex and holistic, and was formulated on civilization theory level. The only methodologically acceptable approach is the multi-criteria definition. The changing role and quantity of information are only one aspect in a multi-criteria system, even if the conventional name coined for the new "society paradigm" is "information", giving "body" to the empty term "post-industrial."

T2. Since the information density is the only new phenomenon in the contemporary societies, there is a need for a well established theory on the role of information in them

A very great number of thinkers do not share this concept of the "only new phenomenon" about the information density, but it is TRUE that new theories on the role of information in contemporary societies would be fruitful for further scientific debates, refreshing the existing theories. It probably helps to define the information society strictly and more colourfully, but this is not a prerequisite.

T3. The Theories of the Information Society is just accidentally about the "Information Society" narrative itself: it is about information-related approaches in contemporary social sciences

TRUE: But it should be highlighted that the book is NOT about the Information Society domain. On the other hand, there are a lot of social science contributions mapping the contemporary information domain, far more better and detailed way, than the selected authors in this book. ${ }^{8}$

T4. There is no unified, complex, holistic concept, only different, analytically separable approaches, "various images of the information society"

FALSE: The cited approaches are not information society theories; they are dealing with given aspects (sub-systems) of the information society. The real concept of information society is an aggregate of all aspects (which means that we can find a lot of approaches other than the Websterian "six").

T4.1. Alvin Toffler's "third wave" concept is a technological definition

\footnotetext{
${ }^{8}$ See for example Brown-Duguid (2002)
} 
FALSE: Toffler's metaphor is definitely not about the technology: it is about a complex, global civilizational change.

T4.2. Identifying the information industries, Fritz Machlup is a pioneer information society thinker.

FALSE: Fritz Machlup has never been an information society thinker. He was involved in totally different discourses.

\section{T4.3. Daniel Bell's definition of information society is occupational.}

FALSE: Bell's theory on post-industrial society is based on a very complex, multi-criteria model.

T4.4. The "spatial approach" is about networks and information flow - and the information society is defined by the presence of networks.

FALSE: Nobody defines the information society by the presence of networks, and the spatial approaches are mainly based on the information patterns of urbanization.

T5. More information does not result in a radically new society, despite of the assumptions of "enthusiasts." There is no reason to call this a "new" information society.

More information results in a radically new society? There has never ever been such a statement in the information society literature. It is PARTLY TRUE that when "politicians, business leaders and policy makers have taken the 'information society idea' to their hearts"9 (ThIS, p. 2), some phrases can remind us of something similar. But it is a responsibility of a social scientist not to mix the narratives. However, we should not forget that the imperative to define the information society by the role of information is Frank Webster's (see T1 and T2).

T6. It is better not to use the term "information society".

Well, there is enormous space to deal with contemporary information-related social sci-

\footnotetext{
${ }^{9}$ Do not hesitate to add to this list the journalists!
}

ence issues without reflecting the information society narrative (critically): ICT in society, Social Informatics, Internet studies, library and information science, etc.

T7. There are only two authors (Daniel Bell and Manuel Castells) who are on the level of "grand narrative" or "high theory".

DEFINITELY MISTAKEN Jean Gottmann, Daniel Bell, Alvin Toffler, Tadao Umesao, Yoneji Masuda, Alain Touraine and James Beniger are the main thinkers on the "grand narrative level." Manuel Castells has a different scope and different scale.

T8. Jean Baudrillard, Zygmunt Bauman, Herbert Schiller, Anthony Giddens and Jürgen Habermas are important theorists of information society.

FALSE: They do not have any direct connection to the information society theory. ${ }^{10}$ To inviolve them as contributors to the contemporary information research is an accidental interpretation, far from their intentions, identities and self-definitions.

T9. A profound historical foundation is needed instead of the ahistorical approaches.

ABSOLUTELY TRUE, but Frank Webster does not provide us with anything about it (as James Beniger does). The "history of information", "the long history of information revolution" or "the historiography of informationrelated sociological thinking" are not equal with the pure "history of information society": we also have to see its $19^{\text {th }}$ century prehistory, formation, growth, maturation, its spatial patterns of spread on the national and global level starting from its late 50's - early 60's birth in the United States. (The neglected multi-criteria models are precisely pointing out this issue). Constantly talking about the "future information society" in the mainstream

\footnotetext{
${ }^{10}$ I find more useful Christopher May's selection: Walter Benjamin; Murray Edelman; Jacques Ellul; Harold Innis; Lewis Mumford; Karl Polanyi; Eric Elmer Schattschneider and Raymond Williams (May, 2003). The title (Key Thinkers for the Information Society) is also important: May does not present his authors as information society thinkers, just underlines their possible influence in the discourse.
} 
media undermines its more than 60 years old historical nature.

\section{Epilogue}

Since the crucial point of my critique of Webster is the identification of the relevant In- formation Society theories and their nature, in the next part to come l'll present a comparative analysis of the main multi-criteria models, defining and defending the original scope of thinking about the information society.

\section{References}

Brown, J. S. \& Duguid, P. (2002). The Social Life of Information. Boston: Harvard Business Press.

ELIS (2003). Encyclopedia of Library and Information Science. New York: Marcel Dekker.

Gane, N. (2005). An Information Age Without Technology? A Response to Webster. Information, Communication and Society, 8 (4), 471-476.

May, C. (Ed.) (2003). Key Thinkers for the Information Society. London, New York: Routledge.

Rayward W. B. (Ed.) (2008). European modernism and the information society: Informing the present, understanding the past. Aldershot, Hants, England: Ashgate.

Smelser, N. \& Baltes, P. (Eds.) (2002). International Encyclopedia of the Social and Behavioral Sciences. Amsterdam: Elsevier.

Webster, F. (1995). Theories of Information Society. London, New York: Routledge (3rd edition, 2006).

Webster, F. (2002). The Information Society Revisited In: L.A. Lievrouw \& S. Livingstone (Eds.): Handbook of new media (pp. 22-33). London, Thousand Oakfs, New Delih: Sage.

\section{About the Author}

Laszlo Z.Karvalics

Historian, information society researcher, $\mathrm{PhD}$ (49). Chair, Department of Library and Human Information Science, University of Szeged, Faculty of Arts. Founding director (BME-UNESCO Information Society and Trend Research Institute, 19982006), founding editor of the Hungarian language quarterly "Information Society" (2001-2006). Fulbright research scholar in 2007 and 2008 (The Birth of Information Society in the United States) at George Washington and Georgetown University. His latest book on the topic: Information Society Dimensions (JATE Press, 2009, Hardcover, 2010). 